\title{
Oxytocin massage enhanced breast milk production in post-partum women
}

\author{
Lidia Widia, Tuti Meihartati \\ Department of Obstetrics and Gynecology, STIKES Darul Azhar Batulicin, Public Health Center Batulicin I, \\ District of Tanah Bumbu, South Kalimantan, Indonesia
}

\begin{abstract}
ABSTRAK
Tujuan: menentukan peran pijat oksitosin dalam memperlancar produksi ASI dan meningkatkan kenyamanan ibu.

Bahan dan Metode: penelitian ini adalah survey analitik dengan pendekatan cross-sectional, menggunakan data primer melalui kuesioner. Populasi dalam penelitian ini adalah seluruh ibu post partum dengan jumlah 36orang responden. Tehnik sampling yang digunakan adalah Non Probability. Tehnik analisis data menggunakan Uji Chi Square. Data yang diperoleh dianalisis menggunakan uji chi-Square dengan kemaknaan 0,05.

Hasil: analisa uji Chi- Square diperoleh ada hubungan yang bermakna antara pijat oksitosin $(\mathrm{P}=0,001)$ dengan produksi ASI ibu post partum.

Simpulan: pijat oksitosin memperlancar produksi ASI pada ibu post-partum di Puskesmas Batulicin 1, Kabupaten Tanah Bumbu, Kalimantan Selatan. (MOG 2017;25:63-65)
\end{abstract}

\begin{abstract}
Objectives: to determine the role of oxytocin massage in enhancing breastmilk production and improving mother's comfort Materials and Methods: This study was an analytic survey with cross-sectional approach using primary data obtained by means of questionnaire. The population was 36 post-partum mothers recruited using non-probability sampling. Data were analyzed using chi-square test with a significance of 0.05 .

Results: The results of Chi-square test revealed significant correlation between oxytocin massage $(p=0.001)$ and post-partum breastmilk production.

Conclusion: Oxytocin massage enhanced post-partum breastmilk production at Public Health Center Batulicin 1, District of Tanah Bumbu, South Kalimantan. (MOG 2017;25:63-65)
\end{abstract}

Keywords: Oxytocin massage; enhanced breastmilk production

Kata kunci: pijat oksitosin; kelancaran produksi ASI

Correspondence: Lidia Widia, Midwifery Vocational Program, STIKES Darul Azhar Batulicin, Tanah Bumbu, South Kalimantan, Indonesia. Phone: 62-21-38140588. E-mail: lidia_cantika30@yahoo.com

\section{INTRODUCTION}

Breast milk is the most important food for infants especially in the first months of life. Breast milk is an ideal source of nutrition with a composition that suits the needs of infant growth, because breast milk is the most perfect infants' food, both in quality and quantity. Breast milk as a single food adequately meets the needs of normal infant's growth until the age of four to six months. The World Health Organization (WHO) recommends that newborns receive exclusive breastfeeding (without any extras) for six months. ${ }^{1}$ This is because breast milk is the best natural nutrient for infants with the most appropriate nutrient content for optimal growth. $^{2}$ Factors affecting breast milk production include breast care, frequency of feeding, birth weight, age of delivery, maternal age and parity, stress and acute illness, cigarette consumption and contraceptive pills. Factors that inhibit breast milk production include rare breastfeeding or pumping the breast, the baby can not suck the milk effectively, and the mother's nutrition is lacking. ${ }^{3,4}$

In the Province of South Kalimantan in 2014 it was found that infants who get breast milk reached as much as $76 \%$. Infants who were breastfed after one hour post- partum were only $4.25 \%$ and in $26 \%$ breast milk was substituted by formula milk because milk production was less smooth. Based on a survey in the District Tanah Bumbu, in 2015 breastfeeding mothers were as many as 3858 persons and $48.1 \%$ of them provided exclusive breastfeeding until the age of 0-6 months without additional food or drink. In those who did not give exclusive breastfeeding, 51.9\% were due to inhibited milk production resulting in lactation failure. ${ }^{5}$ According to data from Public Health Center Batulicin 1, District of Tanah Bumbu , from January to March 2017 there were 332 postpartum mothers. Breastfeeding mothers with smoothly breastfeeding process were only as many as 112 persons (36.3\%). Most of the mothers with no breast milk production, which was about 220 persons $(60.6 \%)$.

\section{MATERIALS AND METHODS}

This study used analytic survey method with crosssectional approach investigating correlation dynamics between the risk factor (massage of oxytocin) with the effect (smoothness of milk production), by observing and collecting data at a time (point time approach) ${ }^{6-8}$ Populations taken in this study were all postpartum 
mothers at Public Health Center Batulicin 1, District of Tanah Bumbu, South Kalimantan.

Samples in this study were chosen using total sampling. Data were collected from the documentation (register book) of the mothers who visited Public Health Center Batulicin 1. The inclusion criteria of this study were postpartum mothers whose breast milk was not produced and postpartum physiological mothers from 2-hour up to 40 day postpartum. Exclusion criteria in this study were mother not willing to be a respondent, postpartum mothers who have mental disorders, and postpartum mothers who are not in the register book.

The variables tested in this research were the independent variable, that was the oxytocin massage, and the dependent variable, the milk production. Instruments used in this study were questionnaire and checklist. Questionnaires and a direct checklist were used to determine the relationship of oxytocin massage to postpartum mother's breastmilk production at Public Health Center Batulicin 1, District of Tanah Bumbu. Data analysis used was univariate analysis to describe characteristics of each variable in this study to characterize the influence of oxytocin massage to breastmilk production. Bivariate analysis was performed to find the correlation between oxytocin massage and postpartum mother's milk production. ${ }^{8}$ Data were analyzed by using $\mathrm{Chi}$ Square (x2) statistical test of with alpha $=0.05$.

\section{RESULTS AND DISCUSSION}

The result of univariate analysis showed that most (72.2\%) of post-partum mothers performed oxytocin massage at Public Health Center Batulicin 1, Subdistrict Simpang Empat, District of Tanah Bumbu, while a small number $(27.8 \%)$ did not do the oxytocin massage. The majority (72.2\%) of post-partum mothers in Public Health Center Batulicin 1, Subdistrict Simpang Empat, District of Tanah Bumbu, had smooth breastmilk production, while a small number (27.8\%) had no smooth breastmilk production. ${ }^{5}$

The result of bivariate analysis showed that the oxytocin massage had an effect on the smoothness of breastmilk production. Almost all mothers who frequently did oxytocin massage had smooth breastmilk production, while the rest, a small part, had no smooth breastmilk production. Almost half of all mothers who did not do the oxytocin massage had a smooth breastmilk production, and the rest mostly did not smoothly produce breastmilk. The result of chi square statistical test obtained $p$ value $<0.001<\alpha=0.05$, showing a very close relationship between oxytocin massage and smooth breastmilk production in post-partum mother at Public
Health Center Batulicin 1, Subdistrict Simpang Empat, District of Tanah Bumbu.

In addition to being affected by baby sucking, the release of the hormone oxytocin is also affected by the receptors located in the ductal system. When the duct is widened or softened, oxytocin is reflectively secreted by the pituitary to squeeze the breastmilk from the alveoli. After labor, the suppressive effects of estrogen and progesterone on the hypophysis disappear, the influence of hypophysical hormones reappears, including prolactin. The breasts, which have been prepared during pregnancy, become affected, causing the breast glands to contain milk. Breastmilk production will be faster and more abundant when stimulated as early as possible with breastfeeding.

One of the triggers of breast milk production inhibition is the lack of breast care. Breastmilk production may increase or decrease depending on the stimulation of the breast glands, especially in the first week of lactation. Factors that affect the smoothness of breast milk production include breastfeeding frequency, breast care, birth weight, gestational age, maternal age, stress and acute illness. ${ }^{9}$ The sucking or breastfeeding frequency is at least $8 x / 24$ hours, as the more babies suckle on the mother's breast, the more smoothly the breastmilk production and secretion. Breast care is useful to affect the pituitary to release the hormones prolactin and oxytocin. The hormone prolactin affects the amount of breastmilk production and the hormone oxytocin affects the breastmilk secretion. ${ }^{10}$

Foods consumed by breastfeeding mothers are very influential on breastmilk production. When the mother eats food with enough nutrition and with a regular diet, breastmilk production will run smoothly. Low birth weight babies have a lower breastfeeding ability than normal-born babies, because the weight difference affects the prolactin and oxytocin hormone stimuli in the production of breast milk. Age of pregnancy during childbirth affects the ability of the baby to suck so that the resulting breastmilk production is not optimal. Stress and acute illness can interfere with breastmilk production, so the mother should be relaxed and comfortable. ${ }^{11}$

Spinal and neurotransmitters massage and stimulation will stimulate the medulla oblongata to directly send messages to the hypothalamus in the posterior pituitary to release oxytocin, causing the breast to release milk. This spinal massage also relaxes the tension and relieves stress so that the oxytocin hormone is released and will help the mother's breastmilk secretion, assisted by the baby's sucking on the nipple as soon as the baby is born in normal condition. Breastfeeding may be affected by two factors: production and secretion. Breast milk pro- 
duction is affected by the hormone prolactin while its secretion is affected by the hormone oxytocin. The hormone oxytocin is released through the stimulation to the nipple through the baby's sucking or through the massage of the mother's spine. By doing the massage on the spine, the mother will feel calm, relax, increase the threshold of pain and love the baby, so that the hormone oxytocin is released and the breastmilk is quickly secreted. ${ }^{12}$

This study was not consistent with a study conducted by Kent et al (2006) which found that there was no correlation between volume and frequency of breastfeeding per day with mothers' breasmilk production of 24 hours. $^{13}$ Allegedly, this was because in this study there were confounding variables of infants' weight, where in this study the infants' weight before and after breastfeeding was influenced by the volume of breast milk in the mother's breast.

Limitations in this study related to data collection. The data were collected using questionnaire that measured all variables involved in this study. Data collection using questionnaires tends to be subjective so that the honesty of respondents determines the truth of the data provided. In addition, another limitation was communication. Communication with the respondent is very important because the purpose of the conversation will be achieved. In this study there were barriers of language problems. The languages used by respondents were Banjar and Bugis regional languages, which the author were less able to understand.

\section{CONCLUSION}

Oxytocin massage enhanced breastmilk production in post-partum mothers at Public Health Center Batulicin 1, Subdistrict Simpang Empat, District of Tanah Bumbu, South Kalimantan.

\section{REFERENCES}

1. WHO. Millenium and development Goals, Situasi dan pencapaiannya sekarang ini di Indonesia. 2011: 63.

2. Manuaba IBG. Ilmu Kebidanan, Penyakit Kandungan, dan Keluarga Berencana. Jakarta:EGC; 2008, p. 122.

3. Anggraini Y. Asuhan kebidanan pada masa nifas. Yogyakarta: Salemba Medika; 2010. p. 47.

4. Prawirohardjo S. Ilmu Kebidanan. 4th edn. Jakarta: Bina Pustaka; 2009. p. 94.

5. Dinas Kesehatan Kalimantan Selatan. Profil kesehatan Kabupaten Tanah Bumbu. 2016.

6. Notoadmodjo S. Metode penelitian kesehatan. Jakarta: Rineka Cipta; 2010. p. 63.

7. Nursalam. Konsep dan penerapan metodologi penelitian ilmu keperawatan. Pedoman skripsi, tesis, dan instrumen penelitian keperawatan. Jakarta: Salemba Medika; 2008. p. 81.

8. Hidayat AAA. Metode penelitian kebidanan dan teknik penulisan ilimiah. Jakarta: Salemba Medika; 2007. p. 49.

9. Saleha S. Asuhan kebidanan pada masa nifas. Jakarta: Salemba; 2010. p. 101.

10. McClellan HL, Hepworth AR, Kent JC, et al Breastfeeding frequency, milk volume, and duration in mother-infant dyads with persistent nipple pain. Breastfeed Med. 2012;7:275-81.

11. Sriwahyanti. Perawatan ibu hamil dan nifas. Jakarta: Mitra Media Publisher; 2012. p. 59.

12. Sunarsih. Asuhan kebidanan pada ibu nifas. Jakarta: Salemba Medika; 2011. p. 69.

13. Kent JC, Mitoulas LR, Cregan MD, et al. Volume and frequency of breastfeedings and fat content of breast milk throughout the day. Pediatrics. 2006; 117(3):e387-95. 